\title{
PENGARUH PENAMBAHAN GUM ARAB TERHADAP KARAKTERISTIK FISIKOKIMIA DAN SENSORIS FRUIT LEATHER NANGKA (Artocarpus heterophyllus)
}

\author{
EFFECT OF ARABIC GUM ADDITION ON PHYSICOCHEMICAL AND SENSORY \\ PROPERTIES OF JACKFRUIT (Artocarpus heterophyllus) FRUIT LEATHER
}

\author{
Danar Praseptiangga $^{1 *}$, Theresia Pramita Aviany ${ }^{1}$, Nur Her Riyadi Parnanto ${ }^{1}$ \\ Program Studi Ilmu dan Teknologi Pangan, Fakultas Pertanian, Universitas Sebelas Maret (UNS) Surakarta, Jl. \\ Ir. Sutami 36 A, Kentingan, Surakarta 57126, Indonesia \\ * Corresponding author: dpraseptiangga@staff.uns.ac.id
}

\begin{abstract}
ABSTRAK
Fruit leather merupakan salah satu produk makanan ringan dari bubur buah (puree) yang dikeringkan dalam oven atau dehidrator. Penelitian ini bertujuan untuk mengetahui pengaruh penambahan gum arab $(0,3 \%$, $0,6 \%$ dan $0,9 \%$ ) terhadap karakteristik fisikokimia dan sensoris fruit leather nangka. Penelitian ini menggunakan desain penelitian rancangan acak lengkap dengan satu faktor. Hasil penelitian menunjukkan bahwa penambahan gum arab memberikan pengaruh pada karakteristik fisikokimia antara lain; peningkatan kuat tarik (tensile strength), kadar abu, gula reduksi, serat pangan (dietary fiber), dan penurunan kadar air dan aktivitas air (Aw). Pengaruh penambahan gum arab ini terhadap karakteristik sensoris antara lain penurunan nilai pada parameter warna dan meningkatkan nilai pada parameter rasa, aroma, tekstur, dan overall. Fruit leather nangka yang memiliki karakteristik fisikokimia dan sensoris terbaik adalah fruit leather nangka dengan penambahan $0,9 \%$ gum arab.
\end{abstract}

Kata kunci : fruit leather, nangka, gum arab, fisikokimia, sensoris

\begin{abstract}
Fruit leather is one of snack foods made from fruit's puree and dried in oven or dehydrator. This study aimed at determining the effect of arabic gum addition $(0,3 \%, 0,6 \%$ and $0,9 \%)$ on physicochemical and sensory properties of jackfruit fruit leather. The experimental design of completely randomized design (CRD) with one factor was used in this study. Results showed that physicochemical properties of jackfruit fruit leather were affected by arabic gum addition. The higher concentration of arabic gum, the higher tensile strength, ash content, reduction sugar content, and dietary fiber content, whereas the lower moisture content and water activity (Aw). From the sensory analysis by hedonic test, the arabic gum addition affected the level of panelists acceptance on sensory attributes, including taste, aroma, texture, and overall parameters. Jackfruit fruit leather with an addition of $0,9 \%$ of arabic gum was the best fruit leather based on its physicochemical and sensory properties.
\end{abstract}

Keywords : fruit leather, jack fruit, arabic gum, physicochemical, sensory

PENDAHULUAN

Fruit leather berbentuk lembaran tipis dengan ketebalan 2 - 3 mm, kadar air $10-15$ $\%$, mempunyai konsistensi dan rasa khas sesuai dengan jenis buah-buahan yang digunakan. Kriteria yang diharapkan dari fruit leather adalah warnanya yang menarik, teksturnya yang sedikit liat dan kompak, serta memiliki plastisitas yang baik sehingga dapat digulung atau tidak mudah patah (Historiarsih, 2010). Fruit leather dapat dibuat dari beberapa buah dengan flavor yang kuat dan mengandung pektin yang cukup tinggi seperti yang telah dilakukan pada penelitian-penelitian sebelumnya yaitu fruit leather berbahan dasar buah pepaya (Raab C et al., 2000), campuran sirsak rosella (Historiarsih, 2010), jambu mete (Nurlaely, 2002), nangka (Okilya et al., 2010), mangga 
(Azeredo et al., 2006), campuran mangga rosella (Safitri, 2012), campuran nanas dan pisang (Tatali, 2010), jambu (Babalola et al., 2002) dan buah jeruk siam pontianak (Hermawan, 2012).

Salah satu buah asli Indonesia yang masuk dalam kriteria bahan dasar pembuatan fruit leather adalah buah nangka (Artocarpus heterophyllus). Buah nangka (Artocarpus heterophyllus) merupakan salah satu buah Indonesia yang berbuah sepanjang musim dan memiliki flavor yang cukup kuat. Tingkat produksi buah nangka di Indonesia berdasarkan data Badan Pusat Statistik mencapai 652.981 ton pada tahun 2011. Dalam 100 gram buah nangka matang mengandung 27.6 gram karbohidrat, $7 \mathrm{mg}$ vitamin C, 70 gram air, $2.31 \%$ serat, vitamin B1, protein, lemak, kalsium, fosfor dan zat besi (Rahmaniar, 2006). Buah nangka biasa dikonsumsi dalam bentuk segar, jam, jelly, kripik, selai dan puding. Seiring berkembangnya ilmu dan teknologi, buahbuah lokal seperti nangka ini dapat dikembangkan menjadi berbagai produk yang dapat memperpanjang umur simpan, meningkatkan nilai ekonomis dan mempertahankan kandungan nutrisi di dalamnya.

Sebagai bahan dasar pembuatan fruit leather buah nangka masih memiliki kelemahan yaitu kandungan pektin dalam buah yang cukup rendah. Rendahnya kandungan pektin dalam buah nangka memungkinkan tekstur fruit leather yang terbentuk kurang plastis sehingga diperlukan penambahan bahan pengental. Salah satu bahan pengisi yang umum digunakan adalah gum arab. Gum arab dapat meningkatkan stabilitas dengan peningkatan viskositas dan juga tahan pada proses pengolahan menggunakan panas. Menurut Alikonis (1979), gum arab dapat digunakan untuk pengikatan flavor, bahan pengental, pembentuk lapisan tipis dan pemantap emulsi.

Pengembangan produk olahan fruit leather dengan adanya penambahan hidrokoloid gum arab dapat meningkatkan plastisitas, kandungan serat, dan nutrisi dalam fruit leather. Fruit leather nangka dengan cita rasa buah nangka yang khas dapat menjadi salah satu alternatif snack sehat, praktis dan juga dapat memperpanjang umur simpan serta meningkatkan nilai ekonomis buah nangka. Penelitian fruit leather nangka dengan penambahan gum arab ini bertujuan untuk mengetahui pengaruh penambahan bahan pengental gum arab pada karakteristik fisikokimia dan sensoris fruit leather nangka sebagai informasi ilmiah mengenai fruit leather nangka yang belum banyak diteliti dan menjadi salah satu bentuk pengembangan produk pangan berbahan dasar buah.

\section{METODE PENELITIAN}

\section{Bahan}

Bahan baku utama pembuatan fruit leather nangka adalah buah nangka segar jenis nangka bubur yang berumur \pm 100 hari mulai dari buah terbentuk, yang diperoleh dari desa Kranggan, Kabupaten Temanggung. Gum arab teknis food grade didapatkan dari Toko Multi Kimia Raya Semarang yang diproduksi oleh PT Indesso Niagatama, Purwokerto Jawa Tengah, sorbitol (liquid $70 \%$ ) teknis food grade yang diproduksi oleh PT Sorini, Pasuruan Jawa Timur, dan asam sitrat food grade teknis diperoleh dari CV Agung Jaya Surakarta, diproduksi oleh PT Budi Acid Jaya, digunakan sebagai bahan pembantu dalam pembuatan fruit leather ini. Bahan kimia yang digunakan untuk analisis antara lain glukosa $\left(\mathrm{C}_{6} \mathrm{H}_{12} \mathrm{O}_{6}\right)$, reagensia Nelson, reagensia Arsenomolybdat, buffer fosfat, enzim thermamyl, enzim pankreatin, asam klorida $(\mathrm{HCl} 4 \mathrm{~N})$, natrium hidroksida $(\mathrm{NaOH} 4 \mathrm{~N})$, etanol $\left(\mathrm{C}_{2} \mathrm{H}_{5} \mathrm{OH}\right) 95 \%$, aseton, dan aquades.

\section{Alat}

Alat yang digunakan dalam penelitian antara lain pisau, panci steam, loyang, blender, cabinet dryer (TEW Tipe IL-80EN), spatula karet, neraca analitik, gelas ukur, sendok, botol timbang, oven (Memmert), neraca analitik (Ohaus Adventurer ${ }^{\mathrm{TM}}$ ), desikator, tabung reaksi (pyrex), pipet volume, erlenmeyer, labu ukur 
spektrofotometer UV-vis mini 1240 Shimadzu dan vortex (Heidolph REAX Control), Lloyd's Universal Testing Instrumen (Zwick ZO.5), water bath, oven, gelas beker, Aw-meter (pAwkit), nampan, dan kertas borang pengujian.

\section{Tahapan Penelitian}

\section{Pembuatan puree buah}

Proses pembuatan fruit leather nangka diawali dengan proses pembuatan bubur buah nangka. Buah nangka yang dipilih adalah buah dengan kondisi baik, berwarna kuning cerah, buah lunak, beraroma kuat, dan tidak cacat. Buah nangka selanjutnya dibelah untuk dipisahkan dengan biji buahnya, selanjutnya dicuci dan dilanjutkan dengan proses steam (pengukusan diatas uap air) selama 15 menit untuk menginaktifasi enzim penyebab pencoklatan, melunakkan tekstur buah dan meningkatkan permeabilitas dinding sel bahan sehingga mempercepat proses pengeringan. Selanjutnya buah nangka dihancurkan dengan blender dengan penambahan air (rasio air:bubur; 1:2) selama 5 menit. Asam sitrat $0.2 \%$, gum arab $(0.3 \%$, $0.6 \%$ dan $0.9 \%$ ) dan sorbitol $9,8 \%$ selanjutnya ditambahkan pada bubur buah nangka. Kemudian dilakukan homogenisasi dengan blender selama 2 menit sampai semua adonan tercampur dengan rata. Penentuan konsentrasi gum arab, puree buah dan sorbitol berdasarkan penelitian yang dilakukan oleh Murdinah (2010) dan percobaan pendahuluan (trials). Tujuan dari penambahan sorbitol untuk memberikan rasa manis dan membantu pembentukan gel dalam fruit leather. Sedang penambahan $0,2 \%$ asam sitrat berdasarkan pada hasil trials bertujuan untuk menurunkan tingkat keasaman puree nangka. Formula yang digunakan dalam pembuatan fruit leather nangka dapat dilihat pada Tabel 1.

Tabel 1. Formula Fruit leather Nangka

\begin{tabular}{lcccc}
\hline Bahan & \multicolumn{4}{c}{ Formula (\% gram) } \\
\cline { 2 - 5 }$(\mathrm{b} / \mathrm{b})$ & Kontrol & $\mathrm{A} 1$ & $\mathrm{~A} 2$ & $\mathrm{~A} 3$ \\
\hline Puree & 90 & 90 & 90 & 90 \\
Gum arab & 0 & 0.3 & 0.6 & 0.9 \\
Asam sitrat & 0.2 & 0.2 & 0.2 & 0.2 \\
Sorbitol & 9.8 & 9.8 & 9.8 & 9.8 \\
\hline
\end{tabular}

\section{Pembuatan fruit leather}

Pada proses pembuatan fruit leather, bubur buah yang telah dicampur dengan bahan-bahan tambahan selanjutnya dicetak dengan ketebalan $\pm 2-3 \mathrm{~mm}$ diatas loyang berukuran $28 \times 30 \mathrm{~cm}$ yang telah dilapisi plastik dengan ketebalan 0,7 mm. Bubur buah nangka yang telah dicetak didalam loyang selanjutnya dikeringkan didalam cabinet dryer dengan suhu $70^{\circ} \mathrm{C}$ selama 7 jam. Fruit leather nangka dipanaskan hingga seluruh permukaannya kering, tidak mengkilat, dan tidak ada bagian yang lengket. Fruit leather yang telah kering kemudian dipotong-potong menjadi ukuran 4 x $4 \mathrm{~cm}$ dan dikemas untuk analisis selanjutnya.

\section{Analisis}

Metode analisis yang digunakan untuk mengetahui pengaruh penambahan gum arab terhadap karakteristik fisikokimia dan sensoris fruit leather nangka yang dihasilkan (Tabel 2.)

Tabel 2. Metode Analisis

Macam Uji Metode

\begin{tabular}{ll}
\hline Kadar air & $\begin{array}{l}\text { Thermogravimetri } \\
\text { (AOAC, 2005) }\end{array}$ \\
$\begin{array}{l}\text { Kadar gula } \\
\text { reduksi }\end{array}$ & $\begin{array}{l}\text { Nelson-Somogyi } \\
\text { (Sudarmadji dkk., 1997) }\end{array}$ \\
Kadar abu & $\begin{array}{l}\text { Dry ash (AOAC, 2005) } \\
\text { Tensile strength }\end{array}$ \\
& $\begin{array}{l}\text { Lloyd Universal Testing } \\
\text { Instrument 1000S }\end{array}$ \\
Serat pangan & $\begin{array}{l}\text { Multienzim (Asp et al, } \\
\text { 1983) }\end{array}$ \\
$\begin{array}{l}\text { Aktivitas air } \\
\text { (Aw) }\end{array}$ & $\begin{array}{l}\text { Aw-meter (Apriantono } \\
\text { dkk., 1989) }\end{array}$ \\
$\begin{array}{l}\text { Analisis sensoris } \\
\text { (kesukaan) }\end{array}$ & $\begin{array}{l}\text { Uji Kesukaan/ Hedonik } \\
\text { (Setyaningsih dkk., 2010) }\end{array}$ \\
\hline
\end{tabular}

Penelitian ini menggunakan Rancangan Acak Lengkap (RAL) dengan faktor tunggal (penambahan gum arab) dengan 2 kali ulangan sampel dan 3 kali ulangan analisis. Data yang diperoleh dianalisis dengan metode one way Analysis of Variance (ANOVA) menggunakan software SPSS versi 17. Apabila terdapat pengaruh oleh perlakuan, 
maka dilanjutkan dengan Duncan's Multiple Range Test (DMRT) pada taraf signifikansi $\alpha$ $=0,05$.

\section{HASIL DAN PEMBAHASAN}

\section{Karakteristik Fisikokimia Fruit leather Nangka dengan Penambahan Gum Arab}

Pengujian karakteristik kimia pada fruit leather nangka dengan penambahan gum arab meliputi pengujian kadar air, kadar abu, gula reduksi, serat pangan (dietary fiber) dan aktivitas air $\left(\mathrm{A}_{\mathrm{w}}\right)$. Karakteristik kimia pada fruit leather nangka dengan penambahan gum arab dapat dilihat pada Tabel 3.

\section{Kadar air}

Kandungan air dalam bahan pangan memiliki peranan yang sangat penting karena dapat menentukan acceptability, kesegaran, dan sangat berpengaruh pada masa simpan bahan pangan, karena air dapat mempengaruhi beberapa sifat fisik antara lain tekstur, kenampakan dan cita rasa makanan (Musfiroh, 2009). Pada Tabel 3. menunjukkan bahwa variasi penambahan gum arab pada fruit leather nangka tidak berpengaruh nyata pada taraf signifikansi 0,05 . Kadar air pada fruit leather nangka tanpa penambahan gum arab (10,35\%), sedangkan kadar air dengan penambahan gum arab pada konsentrasi 0,3 dan 0,6\% mengalami kenaikan. Akan tetapi kadar air fruit leather dengan penambahan gum arab $0,9 \%$ mengalami penurunan hingga mencapai nilai $9,82 \%$. Tinggi rendahnya kandungan air didalam suatu bahan pangan dipengaruhi oleh beberapa hal diantaranya struktur molekul dan kandungan kimia seperti gugus protein, polisakarida, serat ataupun ikatan antara molekul antara senyawa tersebut. Selain hal tersebut adanya senyawa pengikat, penambahan asam dan bahan pemanis juga dapat mempengaruhi kandungan air dalam bahan tersebut. Fruit leather nangka dengan penambahan gum arab dengan konsentrasi dibawah $1 \%$ memiliki kecenderungan untuk meningkatkan kadar air dalam fruit leather. Hal ini dapat disebabkan oleh kemampuan gum arab dalam mengikat air tergolong rendah (water holding capacity). Kapasitas pengikatan air pada gum dapat dipengaruhi oleh protein yang memiliki gugus fungsional yang dapat mengikat air. Apabila dibandingkan dengan jenis hidrokoloid lain, gum arab punya kemampuan mengikat air paling rendah yaitu hanya berkisar 7,49\%. Nilai ini jauh berbeda dengan kemampuan pengikatan air pada jenis hidrokoloid lain seperti gum guar dan gum gathi (mencapai $100 \%$ dan $44,9 \%$ (Torio, 2006).

Kehadiran serat (polisakarida) dalam bahan juga berpengaruh pada proses penyerapan air. Kandungan serat yang tinggi akan meningkatkan kemampuan menyerap air. Hal ini terjadi karena didalam serat terdapat cukup banyak gugus hidroksil bebas yang bersifat polar (Santoso, 1999). Menurut Purwono (1993) polisakarida membentuk butiran-butiran yang kompleks dan pada proses pemanasan atom $\mathrm{O}$ dan $\mathrm{H}$ kecuali pada gugus hidroksil akan memutar membalik sehingga membelakangi permukaan yang mengakibatkan sifat hidrofobik sehingga dapat mengikat senyawa hidrofobik lainnya. Sementara gugus hidroksil tetap menghadap ke permukaan sehingga mampu menyerap air dan berikatan dengan gugus polar lainnya.

Tabel 3. Karakteristik Kimia Fruit Leather Nangka dengan Penambahan Gum Arab

\begin{tabular}{cccccc}
\hline & \multicolumn{5}{c}{ Karakteristik } \\
$(\%)$ & $\begin{array}{c}\text { Air } \\
(\% \mathrm{wb})\end{array}$ & $\begin{array}{c}\text { Abu } \\
(\% \mathrm{wb})\end{array}$ & $\begin{array}{c}\text { Gula } \\
\text { Reduksi } \\
(\% \mathrm{wb})\end{array}$ & $\begin{array}{c}\text { Aktivitas } \\
\text { Air } \\
\left(\mathrm{a}_{\mathrm{w}}\right)\end{array}$ & $\begin{array}{c}\text { Serat } \\
\text { Pangan } \\
(\% \mathrm{wb})\end{array}$ \\
\cline { 2 - 6 } & $10,35^{\mathrm{a}}$ & $1,96^{\mathrm{a}}$ & $17,31^{\mathrm{a}}$ & $0,39^{\mathrm{ab}}$ & $4,16^{\mathrm{a}}$ \\
0,0 & $12,01^{\mathrm{a}}$ & $1,98^{\mathrm{a}}$ & $17,72^{\mathrm{a}}$ & $0,43^{\mathrm{b}}$ & $5,18^{\mathrm{b}}$ \\
0,3 & $11,97^{\mathrm{a}}$ & $1,99^{\mathrm{a}}$ & $18,25^{\mathrm{a}}$ & $0,42^{\mathrm{ab}}$ & $6,03^{\mathrm{c}}$ \\
0,6 & $9,82^{\mathrm{a}}$ & $2,01^{\mathrm{a}}$ & $19,24^{\mathrm{a}}$ & $0,37^{\mathrm{a}}$ & $6,59^{\mathrm{d}}$ \\
\hline
\end{tabular}

Keterangan: notasi yang berbeda menunjukkan perbedaan nyata pada taraf signifikansi $\alpha=0,05$ 
Kehadiran serat (polisakarida) dalam bahan juga berpengaruh pada proses penyerapan air. Kandungan serat yang tinggi akan meningkatkan kemampuan menyerap air. Hal ini terjadi karena didalam serat terdapat cukup banyak gugus hidroksil bebas yang bersifat polar (Santoso, 1999). Menurut Purwono (1993) polisakarida membentuk butiran-butiran yang kompleks dan pada proses pemanasan atom $\mathrm{O}$ dan $\mathrm{H}$ kecuali pada gugus hidroksil akan memutar membalik sehingga membelakangi permukaan yang mengakibatkan sifat hidrofobik sehingga dapat mengikat senyawa hidrofobik lainnya. Sementara gugus hidroksil tetap menghadap ke permukaan sehingga mampu menyerap air dan berikatan dengan gugus polar lainnya. Penambahan asam sitrat dapat memperbaiki sifat koloidal dari larutan yang mengandung pektin (Winarno, 1996). Adanya penambahan asam menyebabkan putusnya ikatan garam dalam protein sehingga meningkatkan gaya tolak menolak elektrostatik dan melonggarkan jaringan protein yang mengakibatkan meningkatkan daya penyerapan air (Wardoyo, 1987).

Selain penambahan asam, proses pemanasan yang lama juga dapat mempengaruhi kemampuan daya ikat air. Pemanasan yang cukup lama dapat menghidrolisis dan mendegradasi gum arab sehingga menurunkan viskositas gum arab dan menurunkan daya ikat air (Purwono, 1993). Proses degradasi ini diduga akibat dari proses denaturasi protein yang terkandung dalam gum arab. (Winarno, 1992; Triyono, 2010).

\section{Kadar Abu}

Analisis kadar abu bertujuan untuk mengetahui banyaknya mineral yang tidak dapat terbakar dari bahan organik melalui proses pembakaran (Sudarmadji, 1997). Berdasarkan Tabel 3 dapat diketahui bahwa kadar abu dalam fruit leather nangka dengan penambahan gum arab mengalami peningkatan dibandingkan dengan fruit leather tanpa penambahan gum arab. Kandungan abu dalam fruit leather nangka dengan penambahan gum arab tidak menunjukan adanya perbedaan nyata pada taraf signifikansi $\alpha=0,05$. Nilai kadar abu pada fruit leather nangka berkisar antara $1,9 \%$ - 2\%. Pada penelitian Ni'mah (2013) kandungan abu pada fruit leather dengan penambahan rumput laut sebesar 1,6-2,3\%. Hal ini tidak berbeda jauh dengan nilai kadar abu pada fruit leather nangka dengan penambahan gum arab. Dari perbandingan tersebut dapat diketahui jika penambahan bahan pengisi berpengaruh pada peningkatan kandungan abu dalam produk yang dihasilkan (fruit leather).

Peningkatan kadar abu pada fruit leather nangka disebabkan oleh adanya penambahan gum arab. Pada gum arab terkandung garam-garam mineral seperti kalsium, magnesim dan potasium yang berasal dari asam polisakarida (Gliksman, 1979). Kandungan abu dalam gum arab mencapai 2\%-4\% (Torio, 2006). Pada proses terbentuknya gel, pektin, dan senyawa hidrokoloid berikatan dengan asam dan juga terjadi pengikatan air. Semakin banyak air yang terikat juga dapat meningkatkan kandungan abu karena didalam air juga terkandung banyak garam-garam mineral, seperti $\mathrm{Ca}, \mathrm{Na}, \mathrm{K}$, dan $\mathrm{Cl}$.

\section{Kadar Gula Reduksi}

Penentuan kadar gula reduksi dalam fruit leather nangka dengan penambahan gum arab dilakukan dengan metode Nelson somogyi. Gula pereduksi merupakan golongan gula (karbohidrat) yang dapat mereduksi senyawasenyawa penerima elektron, semua senyawa monosakarida seperti glukosa, fruktosa, galaktosa dan disakarida seperti laktosa dan maltosa merupakan gula pereduksi. Suatu monomer sebagai gula perduksi diandai dengan ada tidaknya gugus karbonil - $\mathrm{CHO}$ (aldehid) atau -CO (keton) pada struktur monosakarida. Kadar gula reduksi pada fruit leather nangka dengan penambahan gum arab tidak menunjukan perbedaan nyata pada taraf signifikansi $\alpha=0,05$. Dari Tabel 3 dapat terlihat hasil analisis gula reduksi, di mana semakin tinggi konsentrasi gum arab yang ditambahkan maka semakin tinggi pula kadar gula reduksi dalam fruit leather nangka. 
Gum arab merupakan golongan heteropolisakarida. Di dalam gum arab terkandung senyawaan gula yaitu $26,1 \%$ arabinosa, 9,9\% rhamnosa, 40,1\% galaktosa, dan 9,4\% asam glukoronik (Qi et al., 1991). Arabinosa merupakan salah satu senyawa karbohidrat golongan aldopentosa dengan lima atom karbon yang mengandung satu gugus aldehid dan empat gugus alkohol. Arabinosa merupakan gula pereduksi karena memiliki hidroksil bebas (Ali, 2008). Selain kandungan arabinosa, asam glukoronik, dan galaktosa juga merupakan penyusun gum arab yang bersifat sebagai gula pereduksi. Asam glukoronik dan galaktosa merupakan monomer yang berikatan pada rantai glikosidik yang memiliki gugus aldehid bebas. Adanya gugus aldehid bebas menjadikan monomer tersebut bersifat sebagai gula pereduksi. Berdasarkan hal tersebut maka semakin tinggi konsentrasi gum arab yang ditambahkan dapat meningkatkan kandungan gula reduksi dalam fruit leather nangka. Penambahan gum arab pada fruit leather nangka tidak memberikan pengaruh yang signifikan pada peningkatan gula reduksi. Peningkatan kadar gula reduksi dalam fruit leather juga dapat disebabkan adanya komponen gula yang terkandung didalam buah nangka. Komponen gula didalam buah nangka adalah sukrosa dan fruktosa. Fruktosa termasuk sebagai monosakarida yang memiliki sifat pereduksi. Adanya kandungan fruktosa dalam buah nangka juga memiliki pengaruh dalam meningkatkan kadar gula reduksi dalam fruit leather nangka.

Penambahan asam sitrat $0,2 \%$ dalam proses pembuatan fruit leather nangka mampu menurunkan tingkat keasaman puree buah dari pH 5,75 menjadi 4,75. Akan tetapi penambahan asam sitrat belum berpengaruh pada peningkatan gula perdeuksi karena reaksi hidrolisis belum dapat terjadi pada penggunaan asam lemah. Asam sitrat merupakan golongan asam lemah sehingga hanya memiliki kontribusi yang cukup kecil dalam proses hidrolisis polisakarida (Anggraini, 2003). Penambahan sorbitol atau gula alkohol dalam proses pembuatan fruit leather nangka tidak mempengaruhi peningkatan kadar gula reduksi dalam fruit leather. Hal ini dikarenakan sorbitol tidak termasuk dalam golongan gula reduksi karena tidak memiliki gugus karbonil bebas (Suseno dkk, 2008). Kandungan gula reduksi dalam fruit leather nangka menjadi salah satu faktor yang dapat memicu perubahan warna karena dapat memicu terjadinya reaksi Maillard. Semakin tinggi kandungan gula reduksi maka warna dari fruit leather nangka yang dihasilkan akan menjadi semakin gelap (coklat).

\section{Aktivitas Air (aw)}

Hasil analisis aktivitas air $\left(a_{\mathrm{w}}\right)$ pada fruit leather nangka dengan penambahan gum arab dapat dilihat dalam Tabel 3. Menurut Anggraeni (2011) aktivitas air (water activity) didefinisikan sebagai banyaknya air bebas dalam bahan makanan yang dapat digunakan untuk pertumbuhan mikroorganisme. Secara fisik air bebas terikat dalam jaringan matriks bahan seperti membran, kapiler, serat dan pori-pori.

Berdasarkan hasil analisis Aw pada fruit leather nangka dengan penambahan gum arab mengalami peningkatan pada penambahan gum arab $0,3 \%$ dan mengalami penurunan kadar $a_{w}$ pada konsentrasi penambahan gum arab sebesar $0,6 \%$ dan $0,9 \%$. Aktivitas air pada fruit leather nangka dengan penambahan gum arab pada konsentrasi $0,3 \%$ dan $0,6 \%$ lebih besar dibandingkan dengan fruit leather nangka tanpa penambahan gum arab yang hanya mencapai 0,395. $a_{\mathrm{w}}$ pada fruit leather nangka dengan penambahan gum arab $0,6 \%$ tidak berbeda nyata dengan fruit leather tanpa penambahan gum arab. Sedangkan pada fruit leather dengan penambahan gum arab 0,3\% dan $0,9 \%$ masing-masing berbeda nyata dengan fruit leather nangka pada konsentrasi penambahan gum arab lainnya. Penelitian Azeredo (2006) menunjukkan bahwa aktivitas air di dalam fruit leather mangga mencapai 0,62 dan hampir sama dengan aktivitas air dalam penelitian Murdinah (2010) dengan kisaran 0,57-0,72. Sedangkan pada fruit leather nangka memiliki $\mathrm{a}_{\mathrm{w}}$ yang 
lebih rendah yaitu berkisar antara 0,37-0,43. Hal ini dapat disebabkan oleh bahan dasar yang berbeda dan juga penambahan hidrokoloid yang bersifat mengikat air.

Perubahan aktivitas air berbanding lurus dengan perubahan kadar air pada fruit leather nangka. Pada kadar air fruit leather nangka mengalami peningkatan pada konsentrasi penambahan gum arab 0,3\%, $0,6 \%$ dan mengalami penurunan pada konsentrasi penambahan gum 0,9\%. Peningkatan aktivitas air pada fruit leather dapat dipengaruhi oleh kadar air yang terkandung pada fruit leather. Semakin tinggi kandungan air menunjukkan semakin tinggi pula kandungan air bebas yang terkandung. Pada pengujian dengan cara thermogravimetri, kadar air ditentukan berdasarkan banyaknya air yang teruapkan sampai sampel memiliki berat konstan. Semakin tinggi kadar air menunjukkan semakin banyaknya air yang teruapkan pada proses pengeringan, air yang dapat diuapkan termasuk dalam golongan air bebas yang tidak terikat secara kuat. Peningkatan aktivitas air pada fruit leather dengan penambahan konsentrasi gum arab 0,3\% dan $0,6 \%$ dapat disebabkan oleh kemampuan gum arab dalam mengikat air, akan tetapi ikatan yang terbentuk lemah sehingga pada proses pemanasan yang cukup lama ikatan hidrogen dapat terpotong dan melepaskan senyawa air dalam bahan. Hal ini juga dipengaruhi oleh kemampuan pengikatan air (water holding capacity) gum arab yang rendah dibandingkan dengan jenis hidrokoloid yang lain.

Kemampuan mengikat air pada gum arab dipengaruhi oleh adanya senyawa protein didalamnya. Semakin berkurangnya kandungan air maka jarak antara ikatan protein pendek. Hal ini memungkinkan naiknya formasi ikatan sehingga memperketat jaringan protein dan meningkatkan kemampuan pengikatan air (Rustad et al., 1983). Dalam satu gram protein terkandung 0,3-0,5 gram air dan sekitar 4-9\% dari air yang berikatan dengan protein teradsorpsi pada permukaan protein. Ikatan air yang teradsorbsi pada permukaan protein bersifat lemah (Hardman, 1989). Selain penambahan gum arab, asam membantu proses pengikatan air dalam proses pembentukan gel. Penambahan sorbitol juga berperan dalam proses pengikatan air karena selain sebagai bahan pemanis sorbitol juga memiliki sifat sebagai humektan yang dapat mengikat air bebas.

Aktivitas air dalam suatu bahan pangan dapat menentukan daya simpan dari produk itu sendiri. Semakin tinggi aktivitas air maka daya simpan suatu produk akan semakin rendah karena memungkinkan mikroorganisme perusak untuk berkembang. Menurut Anggraeni (2011) mikroorganisme memiliki kemampuan hidup pada rentang $\mathrm{a}_{\mathrm{w}}$ yang berbeda-beda. Bakteri hidup pada $a_{w}>$ 0.9, Khamir hidup pada rentang $\mathrm{a}_{\mathrm{w}} 0,8-0,9$ sedangkan kapang dapat hidup pada rentang $a_{w} 0,6-0,7$. Berdasarkan hasil analisis $a_{w}$ pada fruit leather nangka berkisar antara 0,373 - 0,418 sehingga mikroorganisme tidak memungkinkan untuk tumbuh dan memungkinkan fruit leather nangka tersebut memiliki umur simpan yang lebih lama pada kondisi penyimpanan tertutup di suhu ruang.

\section{Serat Pangan (Dietary Fiber)}

Serat pangan (dietary fiber) adalah bagian dari bahan pangan yang tidak dapat dihidrolisis oleh enzim-enzim pencernaan (Muchtadi, 2001). Hampir sebagain besar serat pangan dalam bahan pangan bersumber dari jenis bahan nabati. Kandungan serat pangan dalam fruit leather nangka dengan penambahan gum arab dapat dilihat pada Tabel 3. Dalam fruit leather nangka kandungan serat pangan berasal dari bahan dasar fruit leather yaitu buah nangka dan sebagian dari gum arab. Santoso (2011) menyampaikan bahwa kandungan serat dalam buah nangka (Artocarpus heterophyllus) berkisar antara $1,4 / 100 \mathrm{~g}$ buah nangka. Komponen serat pangan dalam buah-buahan dan sayuran adalah selulosa, substansi pektat, hemiselulosa dan beberapa jenis glikoprotein. Kandungan serat pangan dalam fruit leather nangka berbeda nyata pada taraf signifikansi 0,05 . Kandungan serat pangan pada fruit leather nangka tanpa penambahan gum arab 
berkisar $4,1614 \%$. Dengan persentase serat pangan larut 2,8\% dan serat pangan tidak larut $1,45 \%$. Semakin tinggi konsentrasi penambahan gum arab menyebabkan kandungan serat pangan dalam fruit leather nangka semakin meningkat. Kandungan serat pangan dalam fruit leather nangka mengalami peningkatan rata-rata $0,809 \%$ setiap penambahan gum arab $0,3 \%$. Peningkatan kandungan serat pangan dalam fruit leather nangka disebabkan oleh penambahan gum arab. Seperti yang disampaikan Muchtadi (2001) bahwa gum arab termasuk dalam golongan serat pangan larut (SDF). Penambahan sorbitol dan asam sitrat tidak berpengaruh pada kandungan total serat pangan dalam fruit leather nangka karena sorbitol dan asam sitrat tidak mengandung komponen serat pangan.

\section{Kuat Tarik (Tensile Strength)}

Analisis sifat fisik fruit leather nangka dilakukan dengan instrumen Lloyd Instrument Testing dengan jenis pengujian kuat tarik. Hasil analisis kuat tarik (tensile strength) pada fruit leather nangka dapat dilihat pada Gambar 1.

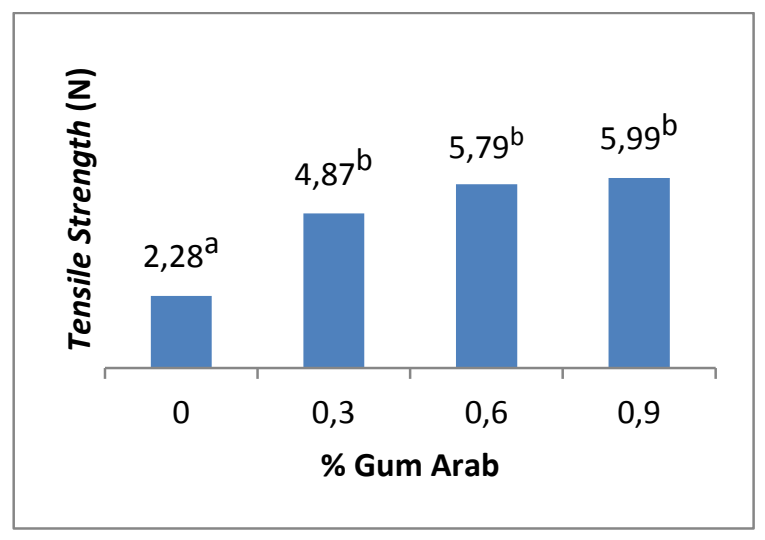

Gambar 1. Tensile Strength Fruit leather Nangka dengan Penambahan Gum Arab

Kuat tarik diuji dengan cara menarik fruit leather dengan menggunakan alat Lloyd Universal Testing Instrument hingga putus. Kuat tarik dihitung berdasarkan gaya (Fmax) yang dibutuhkan untuk meregangkan fruit leather hingga terputus. Kuat tarik (tensile strength) fruit leather nangka dengan penambahan gum arab 0,9\% meningkat hingga mencapai 5,99 N. Semakin besar penambahan gum arab maka tingkat ketahanan tarik dari fruit leather nangka menjadi semakin tinggi. Salah satu syarat dari fruit leather adalah memiliki tekstur plastis sehingga dapat digulung. Tekstur plastis dari fruit leather nangka dibentuk dari proses pembentukan gel. Proses pembentukan gel dalam fruit leather terjadi selama proses pemanasan dengan adanya pektin, asam, air, dan senyawa hidrokoloid.

Mekanisme pembentukan tekstur gel dalam fruit leather dimulai dengan adanya proses gelasi yang melibatkan (asosiasi) ikatan silang dari rantai-rantai polimer untuk membentuk jaringan tiga dimensi secara kontinyu dan mampu memperangkap cairan, membentuk tekstur kaku, kokoh dan tahan saat diberikan suatu tekanan. Proses pembentukan gel dipengaruhi oleh ikatan antara gula, derajat percabangan, derajat polimerisasi, adanya ion logam, dan hidrokoloid (Rachmawati, 2009). Menurut Astuti (2011), elastisitas yang terbentuk oleh adanya senyawa hidrokoloid memiliki sifat yang baik, namun tidak efisien sebagai penahan uap air karena bersifat hidrofil. Untuk mengatasi hal tersebut perlu ditambahkan plasticizer. Sorbitol yang ditambahkan dalam fruit leather memiliki sifat memperbaiki tekstur plastis. Sorbitol memiliki kelebihan untuk mengurangi ikatan hidrogen internal pada ikatan intermolekul sehingga baik untuk menghambat penguapan air dari produk (Astuti, 2011). Sorbitol juga dapat menjaga protein sehingga protein tersebut tidak terdenaturasi dengan cepat (Aminudin dkk, 2013). Kekuatan gel yang terbentuk selain dipengaruhi oleh adanya penambahan senyawa hidrokoloid juga disebabkan adanya interaksi antara asam dan protein yang terkandung dalam bahan dan gum arab. Asam bersifat memperkuat ikatan dalam struktur gel yang terbentuk (Aminudin dkk, 2013).

\section{Karakteristik Sensoris}

Analisis karakteristik sensoris pada fruit leather nangka dilakukan dengan uji 
kesukaan metode skoring. Karakteristik sensoris yang diujikan meliputi parameter warna, aroma, rasa, tekstur, dan overall.

Dari analisis sensoris yang dilakukan oleh 30 orang panelis diketahui jika tingkat penerimaan konsumen pada warna fruit leather nangka tidak berbeda nyata pada taraf signifikansi $\alpha=0,05$. Rata-rata nilai kesukaan panelis berkisar antara 3,33- 3,70 (Tabel 4.). Tingkat penerimaan tertinggi ada pada fruit leather tanpa penambahan gum arab dan terendah ada pada fruit leather dengan konsentrasi penambahan gum arab tertinggi. Berdasarkan hasil tersebut diketahui jika semakin tinggi penambahan gum arab, maka tingkat kesukaan konsumen pada warna fruit leather akan semakin menurun.

Warna fruit leather nangka yang disukai oleh konsumen adalah kuning cerah sedangkan fruit leather nangka yang kurang disukai berwarna kuning kecoklatan. Perubahan warna atau pencoklatan yang terjadi pada fruit leather nangka disebabkan oleh adanya reaksi maillard. Reaksi maillard terjadi akibat adanya reaksi antara gugus amino primer atau bebas dari protein dengan aldehid atau keton dari gula pereduksi dan menghasilkan senyawa berwarna coklat (Suseno dkk, 2008). Terjadinya reaksi maillard dalam fruit leather nangka diduga disebabkan oleh adanya protein yang terkandung didalam gum arab. Selain adanya kandungan protein, gum arab juga mengandung molekul monosakarida yang bersifat sebagai gula pereduksi. Penambahan sorbitol sebagai pemanis dalam fruit leather nangka tidak berpengaruh dalam proses pencoklatan karena sorbitol merupakan gula alkohol dan tidak memiliki sifat pereduksi.
Dengan demikian dapat diketahui jika penambahan gum arab menyebabkan warna pada fruit leather nangka menjadi coklat. Semakin banyak gum arab yang ditambahkan maka akan menyebabkan warna pada fruit leather nangka menjadi semakin coklat dan menur

Aroma merupakan salah satu sifat sensoris yang ingin dipertahankan dalam fruit leather nangka. Fruit leather nangka yang diharapkan memiliki aroma khas buah nangka. Tingkat kesukaan konsumen terhadap fruit leather nangka dengan penambahan gum arab menunjukkan perbedaan nyata pada taraf signifikansi $\alpha=$ 0,05 . Tingkat kesukaan tertinggi pada aroma fruit leather nangka terdapat pada fruit leather nangka dengan konsentrasi penambahan gum arab 0,9\%. Sedangkan tingkat kesukaan pada aroma fruit leather nangka terendah ada pada fruit leather nangka tanpa penambahan gum arab.

Semakin tinggi konsentrasi gum arab yang ditambahkan dalam fruit leather nangka semakin tinggi nilai kesukaan konsumen terhadap aroma fruit leather. Gum arab selain berfungsi sebagai bahan pengental, gum juga bersifat sebagai mikroenkapsulator. Gum arab memiliki sifat yang baik untuk mempertahankan aroma. Dalam Gliksman (1979) dikatakan apabila gum arab dapat melapisi senyawa aroma dari reaksi oksidasi, evaporasi, dan absorbsi air dari udara terbuka terutama untuk produk higroskopis.

Rasa pada fruit leather tidak jauh berbeda antara fruit leather yang ditambahkan gum ataupun tanpa penambahan gum arab. Hal ini ditunjukkan pula pada nilai kesukaan terhadap rasa yang tidak menunjukkan beda nyata pada taraf signifikansi 0,05 .

Tabel 4. Karakteristik Sensoris Fruit leather Nangka dengan Penambahan Gum Arab

\begin{tabular}{cccccc}
\hline Gum Arab & \multicolumn{5}{c}{ Karakteristik sensoris } \\
\cline { 2 - 6 }$(\%)$ & Warna & Aroma & Rasa & Tekstur & Overall \\
\hline 0,0 & $3,70^{\mathrm{a}}$ & $3,27^{\mathrm{a}}$ & $3,67^{\mathrm{a}}$ & $3,63^{\mathrm{ab}}$ & $3.57^{\mathrm{a}}$ \\
0,3 & $3,60^{\mathrm{a}}$ & $3,47^{\mathrm{a}}$ & $3,90^{\mathrm{a}}$ & $3,27^{\mathrm{ab}}$ & $3,50^{\mathrm{a}}$ \\
0,6 & $3,62^{\mathrm{a}}$ & $3,37^{\mathrm{ab}}$ & $3,77^{\mathrm{a}}$ & $3,10^{\mathrm{a}}$ & $3,53^{\mathrm{a}}$ \\
0,9 & $3,33^{\mathrm{a}}$ & $3,67^{\mathrm{b}}$ & $3.90^{\mathrm{a}}$ & $3,20^{\mathrm{ab}}$ & $3,73^{\mathrm{a}}$ \\
\hline
\end{tabular}

Keterangan: $1=$ sangat tidak suka, $2=$ tidak suka, $3=$ netral, $4=$ suka, $5=$ sangat suka. Notasi yang sama menunjukan tidak ada beda nyata pada taraf signifikansi $\alpha=0,05$. 
Gum arab yang ditambahkan tidak mempengaruhi rasa pada fruit leather nangka karena gum arab merupakan komponen yang tidak memiliki rasa. Rasa khas dari buah nangka lebih mendominasi pada rasa yang terbentuk pada fruit leather.

Fruit leather nangka menggunakan jenis pemanis sorbitol yang memiliki tingkat kemanisan lebih rendah dibandingkan kemanisan sukrosa atau gula tebu. Penambahan sorbitol tidak menjadikan fruit leather nangka menjadi terlalu manis karena buah nangka sendiri sudah memiliki rasa manis yang cukup kuat. Adanya rasa asam yang timbul dari penambahan asam sitrat memberikan efek asam yang menyegarkan dan menyeimbangkan rasa manis dari buah nangka dan sorbitol. Secara umum fruit leather nangka memberikan rasa khas buah nangka yang masih kuat sehingga saat menikmati fruit leather nangka rasa utama yang muncul adalah rasa khas buah nangka.

Pada fruit leather nangka selain dilakukan pengujian ketahanan putus dengan instrumen (tensile strength), juga dilakukan pengujian tekstur dengan penginderaan untuk mengetahui tingkat penerimaan konsumen pada tekstur fruit leather nangka. Berdasarkan hasil analisis dengan instrumen menunjukkan bahwa semakin besar persentase penambahan gum arab maka tekstur yang terbentuk menjadi semakin liat. Tekstur fruit leather nangka dengan penambahan gum arab yang terbentuk bersifat elastis. Tekstur fruit leather nangka berbeda nyata berdasarkan tingkat kesukaan konsumen pada taraf signifikansi $\alpha=0,05$. Nilai kesukaan tertinggi terhadap tekstur fruit leather nangka adalah 3,27 yaitu fruit leather nangka dengan penambahan gum arab 0,3\%. Penambahan gum arab pada fruit leather nangka menyebabkan tekstur yang terbentuk plastis dan sulit untuk dikunyah. Semakin tinggi konsentrasi gum arab yang ditambahkan menyebabkan tekstur fruit leather semakin liat dan sulit untuk dikunyah. Fruit leather nangka pada penambahan gum arab $0,3 \%$ memiliki tekstur yang lebih lembut dibandingkan dengan konsentrasi penambahan gum arab yang lebih tinggi.
Tekstur yang lembut dan mudah untuk dikunyah merupakan tekstur yang disukai oleh konsumen sehingga fruit leather yang paling disukai adalah fruit leather nangka dengan penambahan gum arab pada konsentrasi yang paling rendah.

Tingkat kesukaan konsumen tidak berbeda nyata antara sampel tanpa ataupun dengan penambahan gum arab. Akan tetapi tingkat penerimaan tertinggi ada pada fruit leather nangka dengan penambahan gum arab $0,9 \%$. Secara keseluruhan fruit leather nangka dengan penambahan gum arab tertinggi diterima oleh konsumen karena memiliki cita rasa khas buah nangka yang masih dipertahankan dan elastisitas yang baik.

\section{KESIMPULAN}

Penambahan gum arab pada fruit
leather nangka berpengaruh pada karakteristik fisikokimia fruit leather nangka antara lain meningkatkan kuat tarik, menurunkan nilai aktivitas air, meningkatkan kandungan serat pangan, dan selebihnya tidak berpengaruh secara signifikan pada kadar abu, kadar air, dan gula reduksi fruit leather nangka. Sedang pada karakteristik sensoris fruit leather nangka, penambahan gum arab berpengaruh secara signifikan dalam meningkatkan tingkat kesukaan pada parameter aroma dan menurunkan tingkat kesukaan panelis pada parameter tekstur. Berdasarkan hasil pengujian secara fisikokimia dan sensoris diperoleh tingkat kesukaan terbaik yaitu fruit leather nangka dengan penambahan gum arab $0,9 \%$.

\section{DAFTAR PUSTAKA}

AOAC. 2005. Official Method of Analysis of the Association of Official Analytical Chemist. Benyamin Franklin Station. Washinton, D.C

Aminudin N, Y.S Darmanto dan A.D. Anggo. 2013. Pengaruh Asam Tanat, Sukrosa 
dan Sorbitol terhadap Kualitas Surimi ikan Swangi (Priacanthus tayenus) Selama Penyimpanan Suhu $-5^{\circ} \mathrm{C}$. Jurnal Pengolahan dan Bioteknologi Hasil Perikanan Vol.2 No.2. Semarang.

Ali R. 2008. Sintesis Ester Arabinovanilat dengan Metode Fischer Menggunakan Pelarut Aseton. Skripsi. Departemen Kimia Fakultas Matematika dan Ilmu Pengetahuan Alam Universitas Indonesia. Depok.

Alikonis, J. J. 1979. Candy Technology. The AVI Publishing Co. WestportConnecticut.

Anggraeni, A. A. 2011. Aktivitas Air dan Aktivitas Mikrobia. Jakarta.

Anggraini F. 2003. Kajian Ekstraksi dan Hidrolisis Xilan dari Tongkol Jagung (Zea mays L.). Skripsi. Fakultas Teknologi Pertanian Institut Pertanian Bogor. Bogor.

Asp, N.G., C.G. Johanson, H. Halmer, and M. Siljestrom. 1983. Rapid Enzymatic Assay of Insoluble and Soluble Dietary Fiber. J. Agric. Food. Chem. (31): 476 -482 .

Astuti, A.W. 2011. Pembuatan Edible Film dari Semirefine Carrageenan (Kajian Konsentrasi Tepung SRC dan Sorbitol). Skripsi. UPN JaTim. Jawa Timur.

Azeredo, H. M.C., E.S. Brito., G.E.G., Moreira, V.L. Farias, and L.M. Bruno. 2006. Effect Of Driying and Storage Time on the Physico-Chemical Properties Of Mango Leather. International Journal of Food Science and Technology (41): 635-638.

Babalola S.O., O.A. Ashaye, O.A. Babalola, J.O. Aina. 2002. Effect of Cold Temperature Storage on the Quality Characterization of Pawpaw and Guava Leathers. Journal Agriculture Science 1 (2): 61-63.

Budiningsih, R. 2010. Faktor-Faktor yang Berpengaruh Terhadap Diversifikasi Konsumsi Pangan Non Beras di
Kabupaten Magelang. Tesis. Program Studi Agribisnis Universitas Diponegoro. Semarang.

Glicksman, M. 1979. Gum Technology in the Food Industry. Academic Press, Inc. London

Hardman, T.M. 1989. Water and Food Quality. Elsevier Science Publiser LTD. USA. P 145-152.

Hermawan, Y. 2012. Variasi Penambahan Tepung Kulit Jeruk Siam Pontianak yang Kaya Akan Kandungan Pektin Pada Pembuatan Fruit Lether Buah Jeruk Siam Pontianak. Proposal Program Pre-Mentoring. Politeknik Negeri Pontianak. Pontianak.

Historiarsih, R.Z. 2010. Pembuatan Fruit leather Sirsak-Rosella. Skripsi. Program Studi Ilmu dan Teknologi Pangan Fakultas Teknologi Industri UPN "Veteran". Surabaya.

Okilya, S., I.M. Mukisa and A.N. Kaaya. 2010. Effect of Solar Drying on The Quality and Acceptability of Jackfruit Leather. Electronic Journal of Environmental, Agricultural and Food Chemistry 9(1): 101-111.

Montenegro, M.A., M.L.Boiero., L. Valle and C.D.Borsarelli. 2012. Gum Arabic: More Than an Edible Emulsifier. Products and Applications of Biopolymers. Department of Chemical. Argentina.

Muchtadi, D. 2001. Sayuran Sebagai Sumber Serat Pangan untuk Pencegah Timbulnya Penyakit Degenaratif. Jurnal Teknologi dan Industri Pangan, Vol XII, No.1. Institut Pertanian Bogor. Bogor.

Murdinah. 2010. Penelitian Pemanfaatan Rumput Laut dan Fikokoloid untuk Produk Pangan Dalam Rangka Peningkatan Nilai Tambah dan Diversifikasi Pangan. Balai Besar Riset Pengolahan Produk dan Bioteknologi Kelautan dan Perikanan. 
Musfiroh. I., W.Indriyati, Muchtaridi dan Y. Setiya. 2009. Analisis Proksimat dan Penetapan Kadar $\beta$-Karoten dalam Selai Lembaran Terung Belanda dengan Metode Spektrometri Sinar Tampak. Jurnal Penelitian Fakultas Farmasi Universitas Padjadjaran. Bandung.

Ni'mah, A.M. 2013. Kajian Karakteristik Kimia dan Sensoris Fruit Leather Beberapa Varietas Pisang (Musa spp.) dengan Variasi Penambahan Rumput Laut (Kappaphycus alvarezii). Skripsi. Program Studi Ilmu dan Teknologi Pangan Universitas Sebelas Maret Surakarta. Surakarta.

Ningsih, E.S., S. Mulyadi, Y. Yetri. 2012. Modifikasi Polipropilena sebagai Polimer Komposit Biodegradabel dengan Bahan Pengisi Pati Pisang dan Sorbitol sebagai Platisizer. Jurnal Fisiska Unand Vol. 1, No. 1, Oktober 2012. ISSN 2302-8491.

Nugroho. E.S., S.Tamaroh dan A. Setyowati. 2006. Pengaruh Konsentrasi Gum Arab dan Dekstrin Terhadap Sifat Fisik dan Tingkat Kesukaan Temulawak (Curcuma Xanthoriza Roxb) Madu Instan. LOGIKA Vol 3 No.2. ISSN: 1410-2315

Nurlaely, E. 2002. Pemanfaatan Buah Jambu Mete untuk Pembuatan Leather. Skripsi. Fakultas Pertanian Universitas Brawijaya. Malang.

Purwono, W. 1993. Pengaruh Penambahan Gelatin dan Gum Arab Terhadap Beberapa Sifat Kembang Gula Jenis Tofee. Skripsi. Jurusan Teknologi Hasil Pertanian Universitas Gajah Mada. Yogyakarta.

Puspasari, K., F. Rusli., S. Mileiva. 2005. Formulasi Campuran Flower Leather dari Bunga Mawar Dengan Ekstrak Rempah-Rempah (Cengkeh dan Kayumanis) sebagai Pangan Fungsional Kaya Antioksidan. Laporan
Penelitian Departemen Ilmu dan Teknologi Pangan IPB. Bogor.

Qi, Wu., C. Fong and D.T.A.Lamport. 1991. Gum Arabic Glycoprotein Is a Twisted Hairy Rope. Journal of Plant Physiol 9:848-855.

Raab C and N. Oehler. 2000. Making Dried Fruit Leather. Extention Foods and Nutrition Specialist. Departement of Agriculture. Oregon State University.

Rachmawati, A.K. 2009. Ekstraksi dan Karakterisasi Pektin Cincau Hijau (Premna oblongifolia. Merr) untuk Pembuatan Edible Film. Skripsi. Universitas Sebelas Maret Surakarta. Surakarta.

Rahmaniar, P.M. 2006. Pengaruh Sifat Kimia dan Pertumbuhan Mikrobia pada Serbuk Buah Nangka (Artocarpus Integra) Selama Penyimpanan. Jurnal Penelitian BIPA Vol.17 No. 29. Palembang.

Rustad, T. and Nesse, N. 1983. Heat Treatment and Drying of Capelin Mince, Effect of Water Binding and Soluble Protein. Journal Food Science 48, 1320-2, 1347

Safitri, A.A. 2012. Studi Pembuatan Fruit Leather Mangga-Rosella. Skripsi. Fakultas Pertanian Universitas Hasanudin Makasar. Makasar.

Santoso, A. 2011. Serat Pangan (Dietary Fiber) dan Manfaatnya Bagi Kesehatan. Magistra No. 75 Th XXIII. ISSN 0215-9511. Klaten Jawa Tengah.

Santoso, B. 1999. Aktivitas Air dan Kemunduran Mutu Jackfruit Leather. Thesis. Universitas Gadjah Mada. Yogyakarta.

Setyaningsih D., Anton A dan Maya P.S. 2010. Analisis Sensori untuk Industri Pangan dan Agro. IPB Press. Hal 5963

Sudarmadji, S., Bambang $\mathrm{H}$ dan Suhardi. 1997. Prosedur Analisa untuk Bahan 
Makanan dan Pertanian. Liberty. Yogyakarta.

Suseno. T.I.P., N. Fibria dan N. Kusumawati. 2008. Pengaruh Pengganti Sirup Glukosa dengan Sirup Sorbitol dan Penggantian Butter dengan Salatrim terhadap Sifat Fisikokimia dan Organoleptik Kembang Gula Karamel. Jurnal Teknologi Pangan dan Gizi, Vol 7 No. 1 April 2008. Surabaya.

Tatali, D. 2010. Pembuatan Fruit Leather dari Campuran Buah Nenas dan Pisang http://epetani.deptan.go.id/budidaya/pe mbuatan-fruit-leather-dari-campuranbuah-nenas-dan-pisang. Diakses pada 25 Januari 2013.

Torio. M.A.O., J.Saez and F.E. Merca. 2006. Physicochemical Characterization of Galaktomannan from Sugar Palm (Arenga saccharifera Labill.) Endosperm at Different Stages of Nut Naturity. Philippine Journal of Science 135(1) 19-30 ISSN 0031-7683.

Triyono, A. 2010. Mempelajari Pengaruh Penambahan Beberapa Asam pada Proses Isolasi Protein Terhadap Tepung Protein Isolat Kacang Hijau (Phaseolus radiatus L.). Seminar Rekayasa Kimia dan Proses. Balai besar Pengembangan Teknologi Tepat GunaLIPI. ISSN: 1411-4216.

Wardoyo, S, A. 1987. Pengaruh Penambahan Natrium Bisulfit, Asam sitrat dan Bahan Pengisi terhadap Mutu Tepung Konsentrat Pisang. Skripsi. Jurusan teknologi Pangan dan Gizi. Institut Pertanian Bogor. Bogor.

Winarno, F.G. 1996. Kimia Pangan dan Gizi. PT. Gramedia Pustaka Utama. Jakarta. 